\title{
CASE STUDY: ORGANOPHOSPHATE POISONING - ATROPINE-INDUCED PSYCHOSIS IN INTENSIVE CARE UNIT PATIENT
}

\author{
VATHSALYA PORANKI* \\ Department of Pharmacy Practice, A.M Reddy Memorial College of Pharmacy Narasaraopet, Guntur, Andhra Pradesh, India. \\ Email: vathsalya17poranki@gmail.com
}

Received: 08 October 2020, Revised and Accepted: 14 November 2020

\begin{abstract}
Organophosphate compounds are used as commercial insecticides and applied as aerosols or dust. Consuming these compounds intentionally or unintentionally lead to dangerous conditions even to fatality. The most common obstacle in treating organophosphorus poisoning is the availability of sufficient medical care, equipment to provide proper emergency care observed in rural areas where there is a lot of gap between intensive care and acute care. Atropine use is as an antidote in organophosphorus poisoning. The dose of atropine mainly depends on the organophosphorus toxic doses. Atropine is a competitive antagonist of acetylcholine at the muscarinic postsynaptic membrane. Atropine blocks all the muscarinic effects in the body. This study presents a case of organophosphorus poisoning treated with atropine leading to atropine psychosis. Patient's conditions, outcomes, and improvements are studied.
\end{abstract}

Keywords: Organophosphate, Poisoning, Atropine, Psychosis, Antidote, Patient.

(C) 2021 The Authors. Published by Innovare Academic Sciences Pvt Ltd. This is an open access article under the CC BY license (http://creativecommons.org/ licenses/by/4.0/) DOI: http://dx.doi.org/10.22159/ajpcr.2021v14i1.39921. Journal homepage: https://innovareacademics.in/journals/index.php/ajpcr

\section{INTRODUCTION}

Organophosphorus compounds are available as dust, granules, or liquids, and some products are required to diluted with water before use [1]. The deaths due to organophosphorus poisoning are increasing in rural areas of India. The organophosphorus compounds are inhibitors of acetylcholinesterase (AchE) enzymes which are responsible for the hydrolysis of acetylcholine (Ach) to choline and acetic acid. Due to the inhibition of acetylcholinesterase enzyme acetylcholine gets accumulated leading to a continued simulation of local receptors, causes paralysis of nerve or muscle. Paralysis is observed foremost in organophosphate (OP) poisoning later causes a complete shutdown of nerve or muscle activity. Apart from (AchE) inhibition, OP also inhibits carboxylic ester hydrolases such as chymotrypsin, butylcholinesterase, plasma hepatic carboxylesterases, and other proteases. OP absorbed through any route such as inhalational, across gastrointestinal (GI), transdermal, and gastrourinary mucosa. The symptoms of OP poisoning usually begin within a few minutes to a few hours after consumption. Symptoms include salivation, lacrimation, urination, diarrhea, GI distress, and emesis. Chronic symptoms include muscle cramps, weakness, gait disorders, anxiety, tachycardia, and blurred vision may be present for several months after treatment [2]. Atropine is considered the most reliable and common antidote in OP poisoning. Atropine is a competitive antagonist of Ach at the muscarinic postsynaptic membrane. Competitive antagonism leads to inhibition of the muscarinic activity of the body. Overdosing of atropine leads to bronchospasm, bradycardia, eye inflammation, non-responsive, and dilated pupils. Coma with circulatory system collapses and respiratory depression, flushed skin, and delirium [3]. The effects of atropine due to its overdosing treat using benzodiazepines such as diazepam, and lorazepam [4]. Physostigmine can also be given as an antidote by slow intravenous infusion rapidly reduces the delirium, coma caused by large doses of atropine. Artificial respiration or mechanical ventilation with oxygen is necessary for severely affected patients [5].

\section{CASE REPORT}

A female patient of age 25 years old weighing $55 \mathrm{~kg}$ admitted to the emergency department on alleged consumption of organophosphorus compound. She has got a pesticide containing organophosphorus from nearby field workers who were using it as a spray on the crop. She took the undiluted form of the granules, identified through the product brought by her family members to the hospital. On consuming, the patient became unconscious with frothing was observed immediately rushed to the ED. The ED doctor performed gastric lavage with activated charcoal patient's condition got worsened to a stage of coma that led to the need for intubation for airway control and shifted to intensive care unit (ICU). Atropine infusion intravenously started on a dose of 1 $\mathrm{mg} / \mathrm{h}$ (stat dose). The patient was in a coma condition for 2 days, gained consciousness, drowsy, and little responsive. After patient was responding to the surroundings yet agitated suggested for Neurophysician consultation when patient was in intensive care unit (ICU) while patient was showing signs of atropine inducing psychosis like non-responsive dilated pupils, delirium, neck muscle, proximal weakness, patient has a within the range of blood pressure, but shown slight tachycardia, blurred vision, chest B/L mild crept. Mechanical ventilation continued for about 5 days on and off. After on atropine infusion for 5 days, psychosis was observed from the $5^{\text {th }}$ day afternoon continued up to the $8^{\text {th }}$ day. Blurred vision, altered sensorium, pinpoint pupils, and mental changes continued until the $10^{\text {th }}$ day of hospitalization.

\section{DISCUSSION}

In organophosphorus poisoned patient though atropine is used as an antidote to counteract the OP action yet larger doses of atropine given for a prolonged time causes psychosis where patients show signs such as muscle twitching, mentally disorganized behavior, and flushed skin. Respiratory depression is one of the severe conditions leading to fatality. Mechanical ventilation with oxygen is the foremost criterion in treatment (Table 1) to prevent respiratory depression. Physostigmine drug can also use as an antidote in OP poisoning drug which was not in stock during the treatment. However, physostigmine causes convulsions, epigastric pain, and salivation reported in several cases. 
Table 1: The treatment regimen of the patient

\begin{tabular}{llll}
\hline Name of the drug & $\begin{array}{l}\text { Route of } \\
\text { administration }\end{array}$ & Dose & Frequency \\
\hline Inj. Pantoprazole & Intravenous & $40 \mathrm{mg}$ & Once a day \\
Inj. Mecobalamin & Intravenous & $5 \mathrm{mg}$ & Once a day \\
Inj. Ceftriaxone & Intravenous & $1 \mathrm{~g}$ & Twice a day \\
Inj. Pralidoxime & Intravenous & $1 \mathrm{~g}$ & Stat \\
Inj. Atropine & Infusion (IV) & $1 \mathrm{mg} / \mathrm{h}$ & Hourly \\
Inj. Lorazepam & Intravenous & $1 \mathrm{mg}$ & Once a day \\
\hline
\end{tabular}

Inj - Injection (drugs administered intravenously as the patient was in an unconscious state)

\section{CONCLUSION}

Organophosphorus pesticide self-poisoning is a clinical problem in many developing countries due to the lack of efficient medical techniques, machinery leading to a severe increase in the fatality rate. Atropine used in a clinical setting, dose modulation, and recording the response of the patient for each dose is essential, especially in poisoning cases. Any overlook when dealing with an emergency case may lead to morbidity. Ensuring patient safety and providing appropriate therapy are crucial in any poisoning cases.

\section{ACKNOWLEDGMENT}

I sincerely thank my ICU doctors and my senior residents who guided in understanding and analyzing the case and sharing their profound knowledge with me. I also thank the patient and her family for being cooperative and giving information regarding the patient details and conditions.

\section{AUTHORS' CONTRIBUTIONS}

Ms. Vathsalya Poranki was involved in collection of data, organizing of data, interpretation of data, case study analysis, preparation, reviewing, and editing of the manuscript.

\section{AUTHORS' FUNDING}

Nil.

\section{ETHICAL COMMITTEE}

Ethical approval was not applicable for case report in our institution.

\section{REFERENCES}

1. Pandit V, Seshadri S, Rao SN, Samarasinghe C, Kumar A, Valsalan R. A case of organophosphate poisoning presenting with seizure and unavailable history of parenteral suicide attempt. J Emerg Trauma Shock 2011;4:132-4.

2. Eddleston M, Buckley NA, Eyer P, Dawson AH. Management of acute organophosphorus pesticide poisoning. Lancet 2008;371: 597-607.

3. Bhattarai MD, Singh DL, Chalise BS, Koirala P. A case report and overview of organophosphate (OP) poisoning. Kathmandu Univ Med J 2006;4:100-4.

4. Johnson MK, Jacobsen D, Meredith TJ, Eyer P, Heath AJ, Ligtenstein DA, et al. Evaluation of antidotes for poisoning by organophosphorus pesticides. Emerg Med Aust 2000;12:22-37.

5. O'Malley GF, O'Malley R. Organophosphate Poisoning and Carbamate Poisoning. MSD Manuals. Kenilworth, NJ: Merck Sharp and Dohme Corporation. 